\title{
A Simulation Study of a Crisis in Southern Africa
}

\section{Citation}

Bates, Robert H. 1970. A Simulation Study of a Crisis in Southern Africa. African Studies Review 13, no. 2: 253-264.

\section{Published Version}

doi:10.2307/523472

\section{Permanent link}

http://nrs.harvard.edu/urn-3:HUL.InstRepos:12211497

\section{Terms of Use}

This article was downloaded from Harvard University's DASH repository, and is made available under the terms and conditions applicable to Other Posted Material, as set forth at http:// nrs.harvard.edu/urn-3:HUL.InstRepos:dash.current.terms-of-use\#LAA

\section{Share Your Story}

The Harvard community has made this article openly available.

Please share how this access benefits you. Submit a story.

Accessibility 


\title{
A SIMULATION STUDY OF A CRISIS IN SOUTHERN AFRICA
}

\author{
Robert H. Bates
}

It is commonplace to refer to southern Africa as an area of confrontation and strife -- an area where conflict between white and black could engulf the southern half of the continent in total warfare. President Kaunda's warning that "warfare in southern Africa would make Vietnam look like a child's picnic" characterizes the opinion of a large number of concerned lookers-on.

Adding to the severity of the situation is the possibility of big-power involvement. With the outbreak of open hostilities in southern Africa, it is possible that the major powers would be seized by a crisis of brinkmanship. Even while failing to lead to war, such a crisis would threaten the modus vivendi which enables the big powers to regulate their conflicts and to forestall armed hostilities.

Motivated in part by these concerns, the arms control project of the Center for International Studies of the Massachusetts Institute of Technology simulated the conduct of American and foreign leaders under conditions of conflict in southern Africa. In this article, I will report on some aspects of CONEX III, as this simulation was called. I I will leave it largely to the reader to assess the validity of the findings and will furnish materials to enable such assessments. Questions of validity aside, the study is an important one. It brings to light the options possibly available to the leaders of black Africa for preserving the peace of the continent while advancing the goals of selfdetermination and majority rule. The interpretations contained in this article are strictly my own and do not reflect the views of the Center, the research director, or any of the other participants in the study.

$I_{\text {The research director was Professor Lincoln Bloomfield, director }}$ of the Center's arms control project. CONEX III was part of the project's study of the control of local conflict. The game took place in March 1969. 
METHODS OF THE STUDY

As one of its research methods, the arms control project employs the technique of political gaming. The technique can be viewed as an attempt to move beyond the confines of experimentation. Experimentation often yields precision at the cost of generalizability. Control and randomization of "extraneous" variables enables the precise assessment of the effects of the "casual" variable of direct concern. In real life, however, there is a multiplicity of variables at play; as a result, experimental evidence may have little bearing on real-life situations.

In political gaming, therefore, researchers attempt to introduce and manipulate a variety of relevant variables. As Raser states,
by building a game that incorporates the central
features of what we wish to study, even if these
features are only rough approximations of the
"real world," we can provide a wide range of stimuli for the human subjects, thereby offering the subjects opportunity for a wide range of possible behaviors. In such a game situation, as in the real world, everything is complicated, messy, and tangled (1969, pp. 37-38).

There is mounting evidence that despite the "willing suspension of disbelief" which is required for gaming, the technique results in surprisingly close approximations to real-life behavior (Gutzgow 1967; Raser 1969, pp. 145-157).

In the southern Africa game, there were three major classes of variables: the decision-makers of the major nations involved, the world scene, and the crisis situation in southern Africa itself. In addition, there was a fourth control variable: different levels of cost consciousness in defense spending among American decision-makers.

\section{The Participants}

The United States and Zambia were the most fully portrayed in the study. The two United States teams -- one for each level of cost consciousness -- included the President and his major military, foreign, and Congressional advisors. The Zambian team was of a similar composition. 
Other political units and decision-makers were represented in a control capacity; that is, their conduct could be directly manipulated by the research director so as to confront the Zambian and United States teams with changing political situations. Included in this group were Britain, France, China, the Soviet Union, the Organization of African Unity (OAU), the Secretary General of the United Nations, Rhodesia, South Africa, Portugal, representatives of the major liberation movements, and radical opinion in the United States.

The actual participants in the game were all highly knowledgeable in international affairs; many had long experience in public affairs and international relations; and many had a deep concern with and knowledge of Africa.2

\section{The World Scene}

The game participants were presented with a "world scene" designed to be credible but to heighten slightly the salience of a crisis in southern Africa. The crisis was set in March 1971. The game participants were informed that Nixon was still President in the United States; there was still a Gaullist government in France; Wilson had not yet called for a general election in Great Britain; and Mao had died but a Mao-like collective leadership retained power in China. Kaunda, Nyerere, Vorster, Smith, and Marcello Caetano remained at the heads of their respective nations.

The players were told that the Vietnam War had substantially deescalated and that Congress was deeply concerned with controlling future international involvements. The Mid-East crisis was explosive as ever. The Soviets had built up their naval forces in the Mediterranean. And while Nasser was clearing the Suez Canal, shipping was still routed about the Cape of Good Hope. AIthough no specific reference was made to the international monetary situation, the players were informed that gold remained the world monetary standard.

\section{The Crisis}

The crisis contained two primary elements: the activities of the liberation movements and foreign manipulation of internal conflicts in Zambia. The participants were told that all the major liberation movements were increasing the frequency and effectiveness of their attacks

For details of this and other Center "games," consult the Publication List published periodically by the Center. 
upon South Africa, Rhodesia, South-West Africa, and the Portuguese Territories. While the government of Zambia did not overtly assist these activities, and in fact hindered them from time to time, it was nonetheless unable to prevent the use of its territory by armed freedom fighters. Equally as unsettling as these incursions were the reprisals upon Zambia by the "white" armed forces. The game participants were briefed on Portugal, Rhodesia, and South Africa's bombing of supposed military camps and guerrilla bases in Zambia. They were also informed of sporadic clashes between Zambia's troops and the troops of the white regimes engaged in "hot pursuit" of fleeing freedom fighters. Adding to the international relevance of the situation was South Africa's use of bases in South-West Africa (Namibia), still regarded by the United Nations as a mandated territory.

The concurrent, putative crisis in Zambia was precipitated by a fall in world copper prices, which in turn entailed severe cutbacks in government spending. The government's determination to maintain and develop its communications with ports on the east coast created the basis for political conflict; for it meant that while cutbacks took place in other provinces in Zambia, government spending continued in the Northern Province. Regional opposition to this pattern of "favoritism," as well as protest over the freezing of wages and prices and other emergency economic measures, precipitated a full-scale crisis in Zambia. The African National Congress (ANC, the major opposition party) rallied dissenting groups and threatened to undermine the government's capacity to handle its financial and political problems. The Cabinet, therefore, called for a general election, making the basis of its campaign the expression of confidence in the government and its emergency programs.

The projected domestic crisis took on an international dimension during the electoral campaign. For the game participants were told it was apparent that ANC was receiving backing from the white regimes in the form of finances, training, and propaganda facilities. Even more aggravating was the increasing presence of well-trained paramilitary groups in opposition territory, who defended ANC candidates, party officials, and "loyal" townships and villages. These armed groups, trained by foreign advisers, soon became involved in open conflict with government personnel and supporters of the United National Independence Party (UNIP, the governing party).

It was reported to the game participants that the Zambian government's alarm at the mounting insurgency had led to the cancellation of the elections and the declaration of a state of emergency in the southern and southwestern areas of Zambia. Following these measures, local UNIP youths attacked the business premises of Europeans who were thought to serve as contacts between ANC and their foreign backers. South African and Rhodesian propaganda expressed alarm at the threatened "pogrom" of whites in Zambia and called for a "Stanleyville operation." 
Stages of the Game

The game continued over two days, involving four move periods in all. In "real time," the game represented a total of three weeks' diplomatic activity.

During the game, the research team monitored each national team over closed-circuit television. Their discussions were recorded and coded by research assistants. The coded material will enable the quantitative tests of hypotheses about international conflict. In addition, assistants recorded in writing all communications between the teams and between the Zambian and American teams and control representatives of South Africa, the OAU, and so forth. When face-to-face negotiations did take place, members of the research staff transcribed the discussions. The documentation thus accumulated forms the basis of this paper and will form the basis of future research.

\section{ANALYSIS OF THE GAME}

Given this mass of material, it is nonsensical to ask: What happened? Rather the questions must be more focused. In this paper, we will ask: What did the game suggest about the likelihood of cataclysmic hostilities in southern Africa? To what extent can the black nations and liberation movements rely upon the United States under crisis conditions? And what is the potential for regional-level control of international conflict in southern Africa?

\section{The Potential for Cataclysm}

For those of us who viewed southern Africa with fear and foreboding, the behavior of the game participants was both puzzling and to a degree reassuring. Rather than pursuing policies of inflexible confrontation, the game participants pursued flexible policies designed to reduce international confrontation. Tempers and frustrations grew as the costs of the sacrifice of cherished values mounted during the game; but the prevailing pattern of behavior was a withdrawal from the brink of open confrontation. The number one, explicit, and often-stated goal of every national team was to reduce provocation and the likelihood of 
armed conflict. 3

An example of this is the behavior of the Zambian team. Despite radical domestic sentiment, their own ideological commitments, and Cabinet-level pressure in support of the liberation movements, the Zambian team, in order to increase its international security, took measures to curtail the activities of freedom fighters. In addition, it constructed policies to ameliorate internal conflict, many of which were designed to reduce the level of international provocation. Thus, for example, the Zambian government initiated a commission of inquiry into the subversive activities of white residents. In so doing, it removed the issue from the control of the Youth Brigade and party activists and placed it in the hands of the legal professions, thereby lessening domestic conflict and reducing the likelihood of confrontation with white regimes.

The South African team evidenced a similar pattern of behavior. Like Zambia, South Africa was concerned with reducing international tensions. Unlike Zambia, South Africa had a greater fear of big-power involvement in southern Africa than of its regional opponent. In short, South Africa's primary concern was to deprive Russia and the United States of reasons for establishing a major presence in southern Africa. As a result of this concern, South Africa took elaborate and highly visible measures to reduce her provocation of Zambia. Thus, for example, the South African government told Zambia not to "be distressed by wild, anti-Zambian statements in the press" and assured Zambia of essential supplies should Rhodesian retaliation and the activities of insurgents cut communications with the south. In addition, South Africa pressured Rhodesia to join her in declaring that while "both governments sympathize with the desire of the Zambian ANC and the peoples of southern Zambia to establish their own freedom," both governments also emphasized their commitment to "non-intervention in the domestic affairs of a foreign country." Through such measures, South Africa sought to replace conflict with cooperation in her relations with Zambia--a policy that bore surprising results, which we will discuss later in the paper.

Portugal pursued a similar policy. Evidence of this is the first communication from the Portuguese to the Zambian government:

The Government of Portugal wishes to assure the Zambian Government that it has no intention of fomenting trouble. To the contrary, it wishes the most cordial relations despite provocation by terrorist groups operating from Zambian soil.

3 While this may not appear to be true for Zambia in the later stages of the game, it must be noted that (a) Zambia's increased intransigence and belligerence was in large part engineered by control, and (b) Zambia, despite its increased hostility, carried out conflictreducing negotiations with both Portugal and South Africa in late stages of the game. 
The Portuguese Government is prepared to enter into discussions with Zambian authorities to insure that further border incidents can be avoided. It assures the Zambian Government that it does not share racial views of South African and Rhodesian Governments....

In conformity with its policy of reducing conflict, the Portuguese government offered assistance in maintaining communications with the coast to compensate for disrupted communications in the south of Zambia and refused to recognize or assist a "government in exile" formed by Zambian opposition leaders. Its primary bargaining counter was Zambia's willingness to frustrate the activities of freedom fighters--a counter which Zambia, perforce, was willing to exchange for Portuguese moderation.

Insofar as the potential for conflagration in southern Africa rests on the commitment of the governments of the region to goals which they consider more important than the objective of peaceful relations, we found that conflagration would be less likely than one would have thought. All the governments had as a primary objective the restoration of peaceful relations, and many made substantial sacrifices to attain that objective.

It should be noted, however, that the design of the game substantially weakens the plausibility of this outcome. One person played Rhodesia and South Africa. It can be questioned whether Rhodesia would or could afford to play as rational a game as South Africa; that one man played both roles may thus have a bias to uniform rationality. Moreover, had the two been played separately, it is doubtful that South Africa could have pressured Rhodesia toward a peaceful settlement as easily as it was able to in the course of our game.

\section{United States Lethargy and Zambia's Reaction}

By far the greatest characteristic of the two United States teams was their lack of direction. Mostly, the teams did nothing. This is not to say that they did not have reasons for their inactivity. But it is to say that, from Zambia's point of view, in the event of a crisis in southern Africa similar to the one depicted in our game--and assuming the validity of our game--the United States would let the regional conflict run its course without substantial assistance or intervention.

The United States was unwilling to furnish military assistance to Zambia. Thus, even though Zambia asked solely for defensive weapons-anti-aircraft batteries to protect against overflights along the line of rail--the United States kept the request "under consideration." The United States, at Zambia's behest, did gain diplomatic assurances from the white regimes of their intention not to violate Zambia's territorial integrity. At no time, however, did the United States threaten sanctions 
upon Portugal or South Africa, despite the numerous economic and military advantages that both derive from their relations with America. 4 The United States considered, but did not provide, economic assistance to Zambia.

The United States' reluctance to intervene on its own was paralleled by a strong preference for multilateral action. Thus, it supported the dispatch of a U.N. observer group to the Zambian-Rhodesian border area and pledged transport for its deployment. Toward the end of the game, one team devoted most of its energies to exploring the possibility of future efforts through the United Nations. In a late memorandum the team noted, "The possibility exists that the G. O. Z. and Soviet Bloc may be presenting an overly alarming picture in an attempt to bring about direct U.S. involvement in Central Africa, so a special effort is necessary to maintain the problem within a U.N. framework." At the end of the game, the other American team was still awaiting the report of a Presidential study commission looking into U.S. policy in southern Africa; from this they hoped to receive some guidance.

The research director took drastic steps to heighten the sense of crisis and the generation of policies in the United States teams. At the beginning of the third game period, the American teams were informed of increased levels of combat. A vast change of policy on Zambia's part, it was reported, resulting from internal political pressure, had led to Zambia's overt support of guerilla activities. They were informed of increased Communist pressures in the form of Russian ships in the Mozambique Channel; Soviet and Chinese assistance to liberation groups and the South African Communist party; and the deployment in Zambia of MIG's from Algerian and SAM-2's from Russia. They were exposed to domestic pressures as well: the formation of liberal citizen groups in support of Zambia, violent protest against United States firms with investments in South Africa, and the creation of a black Malcolm X volunteer brigade, committed to fight on behalf of Zambia and the OAU. Despite the manipulation of these political forces by the research director, the behavior of the United States teams failed to alter.

There were several reasons for the conduct of the American decision-makers. The whole southern Africa question was peripheral to their concerns. Thus, for example, when the Soviets sought to exchange an agreement on nuclear policy (the deployment of the ABM) for America's non-intervention in central Africa, the United States was responsive to the offer. And the United States sought Soviet moderation in the MidEast in exchange for its own non-involvement in Zambia. In both cases, the United States regarded its African policy as negotiable and deferred crucial decisions on that policy. Second, the United States was unwilling to intervene because it feared that once it did become involved, the Soviet Union would have no choice but to do the same. This fear was

${ }^{4}$ It is possible that their responsiveness to United States appeals for moderation obviated the necessity for such threats. 
heightened by an awareness of China's ability to embarrass the Soviet Union were Russia not to act. Last, the United States failed to act because no policy-relevant stereotype was activated by the crisis. For a while, one team did try to place the issue in a human-rights framework; partially as a result, it moved toward increased support for U.N. action. During internal decisions, members of one team explored the relevance of the Sharpeville and Congo experiences; neither seemed to fit. Nor was there enough of a Communist presence to provoke American reactions. As one team member commented after the game,

There were all these reports and all this information coming in, but we couldn't get a handle on it. No one thing seemed to register more than any other. We really didn't know what to make of the situation.

The United States' lethargy was equalled by that of Great Britain. After long delaying a response to Zambia's request for military assistance, Britain dispatched a single unit of paratroopers. By the time the decision was taken, however, the complexion of the crisis had drastically changed and Zambia was unwilling to accept Britain's assistance. The paratroopers remained in Malta.

Zambia's response to the inactivity of the United States and Britain was a natural one: being unable to rely on the Western powers, Zambia turned to the $\mathrm{OAU}$ and the Soviet Union. At first, French pressure on the Francophone states and United States pressure on Ethiopia forestalled concerted OAU action. Later in the game, however, Ethiopia convinced the United States that it was in America's interests that Ethiopia retain the initiative in the OAU; partially as a result, the organization became more active. Under OAU urging, Kenya and Tanzania placed their port and transport facilities at the disposal of the organization and gave priority to military shipments to Zambia. Tanzania offered its southern regions as a staging area. Uganda dispatched an infantry battalion to Zambia; the Sudan sent a squadron of mobile police. Algeria and the UAR dispatched a brigade of infantry to the Tanzania staging area. Algeria and Ethiopia provided fighter planes. The Congo later sent infantry.

Outside of Algeria and Ethiopia's aircraft, OAU assistance was of little value to Zambia. Problems of command and jurisdiction over foreign troops rendered the OAU's aid difficult to utilize. Moreover, the OAU nations were unable to solve Zambia's most pressing problem: air defense for the line of rail, air transport, and tactical air support for ground forces. To fulfill air defense requirements, Zambia turned to the Soviet Union. Before receiving Soviet aid, Zambia had first, at Russia's request, to withdraw its earlier appeal for a U. N. observer mission. Once the request was withdrawn, however, Zambia received all it asked for, with the exception of bombers. 
The Possibility of a Regional Settlement

One of the surprising outcomes of the game was the beginning of the formation of a regional settlement to the conflict. The germs of such a settlement were obvious in the desire of all participants to avoid conflict; and the United States' inability to act may have facilitated the outcome. Whatever the reason, at the end of the game, Zambian and South African representatives negotiated a draft cease-fire agreement. While time precluded an assessment of the Zambian government's response to the efforts of its envoy, it is nonetheless interesting to observe the groundwork he laid for the settlement of international hostilities.

In the negotiations, the South African Foreign Minister criticized Rhodesia for promoting hostilities in central Africa and for threatening to provoke big-power intervention. He noted that it was in the mutual interests of Zambia and South Africa to work for political stability in southern Africa. To this end he proposed a cease-fire.

In reply, the Zambian representative agreed that a cease-fire was imperative and promised no further build-up of Soviet military assistance and the withdrawal of Soviet personnel (at the SAM sites) as soon as possible. Zambia further pledged the release of political prisoners and the free exit of any Europeans who wished to leave.

In response to Zambia's questions, the Foreign Minister of South Africa pledged his government's support for majority rule in Rhodesia. This would be acceptable, he noted, as his government believed in the right of the individual peoples to govern themselves. He promised the use of South Africa's economic strength, in cooperation with the Portuguese, to compel Rhodesia to agree to a full cessation of hostilities. He also pledged the release of Sithole and of all other political prisoners not convicted of heinous crimes. Last, in the event of a rightist coup in Rhodesia, the South African envoy proposed the temporary occupation of Rhodesia. In this way, he concluded, the cease-fire could be enforced on a rebellious Rhodesia.

This, perhaps, is an incredible outcome to the conflict. We do not know if the Zambian team would have accepted it, for time ran out. Nor do we know whether a South African team, representing a cross section of South Africa's political factions, would have allowed such proposals to come from its Foreign Minister; South Africa was represented by one man in the game. The problems arising from having Rhodesia and South Africa represented by one person must also be recalled. In any case, this possible basis for a regional settlement of hostilities in southern Africa was a major product of the game. 


\section{CONCLUSION}

In this paper, we have considered three critical issues raised by the tensions in southern Africa: What is the potential for conflagration? To what extent can the leaders of black Africa rely on the United States in the event of open hostilities? And what is the potential for a regional settlement of international conflict in southern Africa? There remains one last problem. In the light of the game, what would appear to be the most fruitful policy for the leaders of black Africa?

We noted that political gaming can reveal the options available to black Africa for preserving the peace of the continent while advancing the goal of majority rule. Our game began in a period of turmoil. However, by the end of the game, a peaceful settlement was beginning to emerge. The settlement secured one of black Africa's basic demands-majority rule in Rhodesia--and preserved Zambia's territorial and political integrity. What does this relatively favorable outcome suggest about the options open to the policy-makers of black African nations?

The first lesson is obvious. As the game suggests, and as recent events in southern Africa so clearly reveal, majority rule cannot be obtained without international violence. In the short run, peaceful relations and self-determination cannot go together. Given the goal of majority rule, the problem of public policy is not a choice between violent and non-violent methods. Rather, it is a choice of the form of violence that will both yield majority rule and an acceptable level of international security. Taking the outcome of the game as an example of successful policy-making, we can suggest what an acceptable policy would be.

The outcome did not result from Zambia's use of the military power of the black states of Africa. Zambia was too weak to sustain military confrontation. It was open to unlimited reprisals for its assistance to those fighting for majority rule and was nearly torn asunder by the actions of white regimes. Even when Zambia recruited military assistance from other black nations, the mix and scale of their military aid was insufficient to ensure its security, much less to engineer a transfer of power in the southern states of Africa.

Nor was the outcome a result of Zambia's diplomatic efforts among the Western powers. Britain was of no assistance. Zambia could not rely on the United States to preserve its internal or external security. The United States failed to assist in achieving a peaceful settlement of military conflict. And when aid was offered by the United States, it was on terms that amounted to demanding that Zambia openly sacrifice majority rule as a goal of its international policy. 
Rather, the policy which led to the relatively favorable outcome of the game was Zambia's progressive involvement of Soviet military power. It was Soviet aid which furnished Zambia a measure of military security. The intervention of the Soviets also motivated South Africa to reduce the level of international conflict. In addition, Russia's intervention provoked South Africa to grant black Africa's demand for majority rule in Rhodesia.

Our materials thus suggest that the most fruitful policy for the leaders of black Africa might be to amplify the level of conflict in southern Africa to the point where the leaders of the big powers view intervention as necessary or attractive, and then to recruit Soviet support for their position in the conflict. The game suggests that it may be the recruitment of Soviet support which will assist in attaining the goals of the peaceful resolution of conflict, national security, and majority rule.

From America's point of view, this conclusion may be unpalatable. Ironically, it was the gaming of American experts and area specialists that underscored the utility of this option and the bankruptcy--or nonexistence--of America's African policy.

\section{REFERENCES CITED}

Gutzgow, Harold. "Some Correspondences Between Simulations and 'Realities' in International Relations." In Morton A. Kaplan, ed. New Approaches to International Relations. New York: St. Martin's Press, 1967.

Raser, John R. Simulation and Society: An Exploration of Scientific Gaming. Boston: Allyn and Bacon, 1969. 